\title{
Prediction of steady-state verapamil plasma concentrations in children and adults
}

\begin{abstract}
With data on adults from two previous articles it was found that the average steady-state plasma concentration of verapamil in subjects on long-term oral therapy of $80 \mathrm{mg}$ every $6 \mathrm{hr}(Y)$ correlated strongly with the area under the curve from zero to infinity $\left(A U C^{0-x} / 6(X)\right.$ where the area refers to that for a single oral dose of $80 \mathrm{mg}(\hat{Y}=2.41 X, n=15, r=0.923$, $P<0.001)$. Steady-state concentrations are predictable from the single-dose data, with an average absolute deviation of $11.1 \%$. We gave seven children ( 7 to $19 \mathrm{yr}$ old) an initial intravenous bolus dose of $0.1 \mathrm{mg} / \mathrm{kg}$, followed by a 20 -min constant rate infusion of 0.007 $\mathrm{mg} / \mathrm{kg} / \mathrm{min}$. Twenty-four hours after the bolus dose they were put on oral therapy 40 or $80 \mathrm{mg}$ every $6 \mathrm{hr}$ ) and I mo later the minimum steady-state verapamil plasma concentration $\left(C_{s s}^{m i n}\right)$ was measured. Plasma concentration-time data obtained after the infusion were fitted to biexponential (two sets) or triexponential equations (five sets). The coefficients of the postinfusion polyexponential equations were converted to those for the $0.1-\mathrm{mg} / \mathrm{kg}$ bolus dose alone. Mean parameters estimated were: plasma clearance $0.500 \mathrm{l} / \mathrm{min}$, steady-state volume of distribution $279 l, V_{\beta} 394$ l, half-life $9.17 \mathrm{hr}$, and mean residence time $10.0 \mathrm{hr}$. Many correlations were made between the oral $C_{s s}^{\min }$ values and functions obtained from the intravenous data. The best correlation was that between $C_{s s}^{m i n}$ and the predicted steady-state concentration at $3 \mathrm{hr}$ after dosing when bolus doses would be given at 6-hr intervals based on the single-dose intravenous data $(r=0.985, P<0.001)$; this correlation allowed $C_{s s}^{\min }$ to be predicted with an average absolute deviation of $10 \%$. Norverapamil was measured in plasma after oral dosing, but was not detectable after intravenous dosing.
\end{abstract}

\author{
John G. Wagner, Ph.D., Albert P. Rocchini, M.D., and John Vasiliades, Ph.D., \\ Ann Arbor, Mich. \\ College of Pharmacy, The Upjohn Center for Clinical Pharmacology, and Departments of \\ Pediatrics and Pathology, University of Michigan
}

Coronary vasospasm plays a significant role in precipitating myocardial ischemic pain. Verapamil appears to reduce intracellular and, more

\footnotetext{
Supported in part by NIH grant Mo, 1RR00042-21 (Clinical Research Center, University Hospitals).

Received for publication March 1, 1982.

Accepted for publication April 24, 1982.

Reprint requests to: Dr. John G. Wagner, The Upjohn Center for Clinical Pharmacology, University of Michigan, Ann Arbor, MI 48109 .
}

specifically, sarcolemmal calcium stores in the myocardium and is remarkably effective in preventing coronary spasm ${ }^{4}$ and in treating patients with hypertrophic cardiomyopathies.

Verapamil kinetics have been studied in dogs and the changes in arterioventricular conduction time, as estimated from the PR interval of the surface ECG, have been correlated with the logarithm of the plasma verapamil concentration. ${ }^{10}$ The kinetics of the drug were also studied in nor- 


\begin{tabular}{|c|c|}
\hline \multicolumn{2}{|c|}{ Abbreviations used } \\
\hline $\mathrm{AUC}^{(0-x}$ : & $\begin{array}{l}\text { Total area under the } \\
\text { concentration-time curve }\end{array}$ \\
\hline $\mathrm{AUC}^{0-\tau}$ : & $\begin{array}{l}\text { AUC in dose interval at steady- } \\
\text { state }\end{array}$ \\
\hline $\mathrm{Cl}_{\mathrm{po}}^{\text {ss. }}$ & Steady-state oral clearance \\
\hline $\mathrm{Cl}_{p 0}^{\mathrm{s}}$ & Single-dose oral clearance \\
\hline$\overline{\mathrm{C}}_{\mathrm{ss}}:$ & Steady-state concentration \\
\hline $\mathrm{C}_{\mathrm{ss}}^{\min }$ & $\begin{array}{l}\text { Minimum steady-state } \\
\text { concentration }\end{array}$ \\
\hline $\mathrm{C}_{\mathrm{p}}^{\mathrm{iv}}$ & $\begin{array}{l}\text { Predicted plasma concentration } \\
\text { after intravenous dosing }\end{array}$ \\
\hline $\mathrm{V}_{\mathrm{ss}}:$ & $\begin{array}{l}\text { Volume of distribution at steady } \\
\text { state }\end{array}$ \\
\hline GLC: & Gas-liquid chromatography \\
\hline$r^{2}:$ & Coefficient of determination \\
\hline $\mathrm{D}_{\mathrm{po}} / \mathrm{D}_{\mathrm{iv}}:$ & Oral/intravenous dose ratio \\
\hline$t^{1 / 2}:$ & Half-life \\
\hline
\end{tabular}

mal subjects and patients, ${ }^{1-3,5-7,11,12,14,15,22,23}$ but kinetics in children have not been reported to date.

Koup et al. , ${ }^{8,9}$ Slattery et al. ${ }^{17}$ and Slattery ${ }^{18}$ have been remarkably successful in predicting the maintenance dose required to attain a desired drug $\overline{\mathrm{C}}_{\mathrm{ss}}$ from a single determination of concentration after an initial dose. They have also successfully predicted clearance of chloramphenicol in infants and children from a single serum sample obtained $6 \mathrm{hr}$ after the initial intravenous dose. Indirectly such correlations involve relating $\overline{\mathrm{C}}_{\mathrm{ss}}$ of a drug to a single concentration measured after an initial dose.

Recently both Freedman et al. ${ }^{5}$ and Shand et al. ${ }^{15}$ reported that there is a marked reduction in verapamil clearance between the time of the first dose and attainment of steady state. As a result of this, Freedman et al. stated that "kinetic predictions based on single doses will not give reliable estimates for long-term oral dosage." 5 We examined this hypothesis in adults, using the published data of Freedman et al. and Shand et al., and in children, using single-dose intravenous and steady-state oral data we obtained.

\section{Methods}

Adults. Freedman et al. reported the plasma verapamil $A \mathrm{AC}^{0-\infty}$ after a single oral dose $\left(\mathrm{D}_{\mathrm{po}}\right)$ of $80 \mathrm{mg}$ in nine subjects and the $\mathrm{AUC}^{0-\tau}$ after long-term oral doses of $80 \mathrm{mg}$ every $6 \mathrm{hr}$ to the same nine subjects. Shand et al. reported
$\mathrm{AUC}^{0-x}$ after an initial oral dose of $120 \mathrm{mg}$ verapamil in six patients and $\mathrm{AUC}^{0-\tau}$ after the seventh dose of $120 \mathrm{mg}$ every $8 \mathrm{hr}$ in the same patients. We estimated both $\mathrm{Cl}_{\mathrm{po}}^{\mathrm{s}}$ and $\mathrm{Cl}_{\mathrm{po}}^{\mathrm{ss}}$ from $\mathrm{D}_{\mathrm{po}} /\left(\mathrm{AUC}^{0-x}\right)$ and $\mathrm{D}_{\mathrm{po}} /\left(\mathrm{AUC}_{0-\tau}\right)$ from each of the 15 pooled data sets, then correlated $\mathrm{Cl}_{\mathrm{po}}^{\mathrm{ss}}$ with $\mathrm{Cl}_{\mathrm{po}}^{\mathrm{s}}$ using the standard least-squares linear regression method. In addition, the data of Shand et al. were dose adjusted to what would be expected for a unit dose of $80 \mathrm{mg}$, rather than 120 $\mathrm{mg}$, by multiplying the AUCs by $80 / 120$. The average $\overline{\mathrm{C}}_{\mathrm{ss}}$ was then estimated as $\mathrm{AUC}^{0-6} / 6$ with the $\mathrm{AUC}^{0-\tau}$ values of Freedman et al., and in a similar manner from the data of Shand et al., but using the adjusted areas rather than $\mathrm{AUC}^{0-8}$ and 6 rather than $8 \mathrm{hr}$. These $\overline{\mathrm{C}}_{\mathrm{ss}}$ values were correlated with $\mathrm{AUC}^{0-x} / 6$ values by standard least-squares linear regression and least-squares regression where the line is forced through the 0,0 point; for the Shand et al. data the doseadjusted $\mathrm{AUC}^{0-x} \mathrm{~S}$ were used in this correlation.

Children. Our subjects were seven children (two girls; five boys; 7 to $19 \mathrm{yr}$ old; mean age 12 yr) with documented hypertrophic cardiomyopathy. Five of the seven patients were found at the time of cardiac catheterization to have a resting systolic left ventricular outflow tract gradient greater than $10 \mathrm{~mm} \mathrm{Hg}$. All patients were symptomatic as a result of their disease. The symptoms included: marked resting or postexertional dyspnea (all seven patients), chest pain (six patients), and one or more syncopal episodes (four patients).

Routine biochemical investigations revealed normal renal and hepatic function in all patients. No medications were taken in the preceding $48 \mathrm{hr}$. All studies were performed in the fasting state and all seven patients were given morphine sulfate and diphenhydramine as premedication.

Verapamil was given intravenously to all patients at the time of cardiac catheterization. Verapamil $\mathrm{HCl}$ was injected as an initial intravenous bolus of $0.1 \mathrm{mg} / \mathrm{kg}$ over $2 \mathrm{~min}$, followed by a $20-\mathrm{min}$ continuous infusion of 0.007 $\mathrm{mg} / \mathrm{kg} / \mathrm{min}$. The ECG, systemic arterial, left ventricular, and pulmonary artery pressures were continuously monitored. Blood samples ( 5 to $7 \mathrm{ml}$ ) were drawn before verapamil, just as the infusion ceased ( 0 time), and at $0.1,0.25$, 


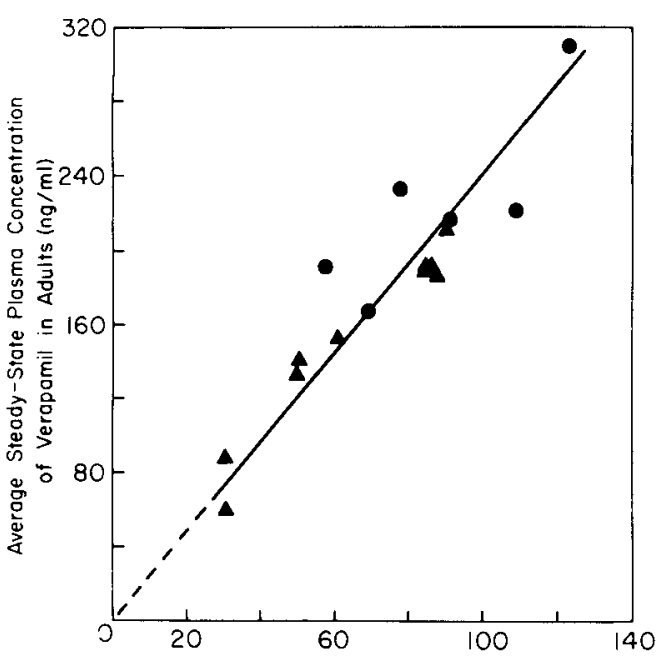

ALC $0^{-\infty} / 6$ After a Single Oral Dose in Adults $(\mathrm{ng} / \mathrm{ml}$ )

Fig. 1. Plot for prediction of average plasma $C_{s s}$ of verapamil from single-dose oral data in adults. Diamonds represent data of Freedman et al. ${ }^{5}$ and circles of Shand et al. ${ }^{1-}$ Equation of line is $\hat{\mathrm{Y}}=2.41 \mathrm{X}$ $(\mathrm{n}=15, \mathrm{r}=0.923, \mathrm{P}<0.001)$.

$0.5,1,2,4,8,12,16,18$, and $22 \mathrm{hr}$ after the infusion. Blood was transferred to heparinized tubes and centrifuged and the plasma was stored at $-20^{\circ}$ until analyzed. Oral dosage was initiated (either 40 or $80 \mathrm{mg}$ every $6 \mathrm{hr}$ ) $24 \mathrm{hr}$ after the bolus dose and a month later a blood sample was taken at $6 \mathrm{hr}$ after a dose at steady state. The latter samples provided the $\mathrm{C}_{\mathrm{ss}}^{\min }$. In one patient (Bo) a single oral dose of $40 \mathrm{mg}$ of verapamil was given $24 \mathrm{hr}$ after the intravenous bolus dose and initiation of the 20-min infusion. For this patient blood was also collected just before oral dosing ( 0 time) and at $0.25,0.5$, $0.75,1,2,3$, and $4 \mathrm{hr}$ after dosing. Verapamil and norverapamil were measured in plasma by a sensitive and specific GLC procedure with a nitrogen-sensitive detector. ${ }^{19}$

Postinfusion verapamil plasma concentrations were computer fitted by the method of least-squares as follows:

$$
\mathrm{C}_{\mathrm{p}}^{\mathrm{iv}}=\sum_{\mathrm{i}=1}^{\mathrm{n}} \mathrm{Z}_{\mathrm{i}} \mathrm{e}^{--\lambda_{\mathrm{i}} \mathrm{t}}
$$

where $n=2$ or $3, Z_{i}$ is the coefficient of the ith term, $\lambda_{i}$ is the exponent of the ith term, and $t$ is time measured from the end of the infusion. Some data sets were fitted with the program NONLIN ${ }^{13}$ with the use of central campus large

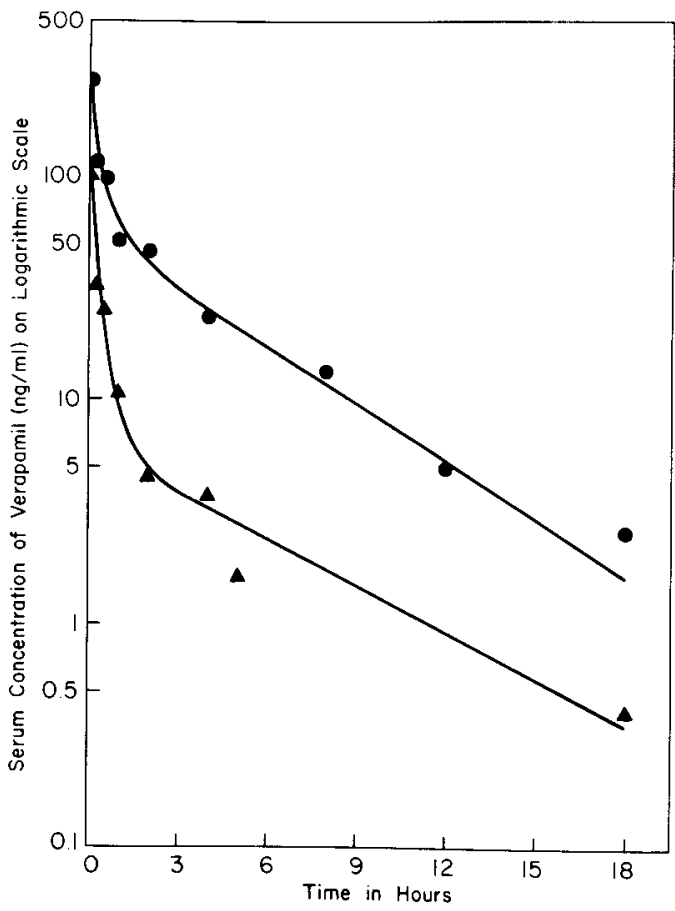

Fig. 2. Semilogarithmic plots of postinfusion data of patients $\mathrm{Me}$ (circles) and $\mathrm{T}$ (diamonds). Lines are computer-fitted concentrations based on equation 1 and the $Z_{i}$ and $\lambda_{i}$ values shown in Table II.

digital computer; the others were fitted with a program written by Dr. J. L. Fox using an Apple II Plus microcomputer. The $Z_{i}$ coefficients were converted to $C_{i}$ coefficients by the method of Singhvi ${ }^{16}$ to provide:

$$
\mathrm{C}_{\mathrm{p}}^{\mathrm{iv}}=\sum_{\mathrm{i}=1}^{n} \mathrm{C}_{\mathrm{i}} \mathrm{e}-\lambda_{1} \mathrm{t}
$$

where the $\mathrm{C}_{\mathrm{i}} \mathrm{s}$ correspond to a bolus dose of 0.1 $\mathrm{mg} / \mathrm{kg}$ of verapamil only and $\mathrm{t}$ is now time after the bolus dose (see footnote to Table II).

A large number of correlations were made to find the optimum parameter to predict the verapamil plasma $\mathrm{C}_{\mathrm{ss}}^{\mathrm{min}} \mathrm{s}$ after long-term oral therapy from the intravenous data. In each case the observed $\mathrm{C}_{\mathrm{ss}}^{\min } \mathrm{s}$ were used as the $\mathrm{X}$ (abscissa) values and an estimated intravenous concentration, corresponding to the oral dose, was calculated from the fitted parameters (coefficients and exponents) obtained from the single-dose intravenous data and used as the $\mathrm{Y}$ (ordinate) values. (The estimated intravenous concentrations used are explained in columns 2 and 3 of, and in the footnotes to, Table VI.) 
Table I. Verapamil plasma concentrations measured after infusion of a bolus dose of $0.1 \mathrm{mg} / \mathrm{kg}$ and an infusion of $0.007 \mathrm{mg} / \mathrm{kg} / \mathrm{min}$ over $20 \mathrm{~min}$

\begin{tabular}{c|c|c|c|c|c|c|c}
\hline \multirow{2}{*}{$\begin{array}{c}\text { Time } \\
\text { postinf } \\
(\mathrm{hr})\end{array}$} & \multicolumn{7}{c}{ Plasma concentration $(\mathrm{ng} / \mathrm{ml})$} \\
\cline { 2 - 8 } & $M a$ & $B u$ & $V$ & $M e$ & $T$ & $H$ & $B o$ \\
\hline 0 & 253 & 304 & 120 & 268 & 101 & 258 & 56 \\
0.1 & - & 140 & - & - & - & 131 & 45 \\
0.25 & 89 & 116 & 60 & 114 & 32 & 82 & - \\
0.5 & 51 & 72 & 24 & 99 & 25 & 57 & - \\
1 & 36 & - & - & 52 & 10.4 & 51 & $26^{*}$ \\
2 & 26 & 64 & $19^{*}$ & 47 & $4.45^{*}$ & $36^{*}$ & $20^{*}$ \\
4 & $13.4^{*}$ & $56^{*}$ & $16^{*}$ & $24^{*}$ & $3.6^{*}$ & - & $12^{*}$ \\
8 & $11.25^{*}$ & - & $14^{*}$ & $13.5^{*}$ & $1.6^{*}$ & $18^{*}$ & 10 \\
12 & $7.6^{*}$ & $15^{*}$ & $9.5^{*}$ & $5.1^{*}$ & - & $13.4^{*}$ & - \\
16 & - & - & - & $-0^{*}$ & - & $8.0^{*}$ & - \\
18 & $6.2^{*}$ & - & - & $2.6^{*}$ & $0.4^{*}$ & - & - \\
22 & - & - & - & - & - & 6.0 & - \\
\hline
\end{tabular}

* Points used to estimate the parameters of the equation $\mathrm{C}=\mathrm{C}_{01} \mathrm{e}^{-\lambda_{z} t}$ in Table V. Parameters were estimated by least squares regression with the equation $\ln C=\ln C_{0}-\lambda_{z}$ t.

\section{Results}

Adults. The correlation of $\mathrm{Y}=\mathrm{Cl}_{\mathrm{po}}^{\mathrm{ss}}$ with $\mathrm{X}=\mathrm{Cl}_{\mathrm{p} 0}^{\mathrm{s}}$ gave the regression line $\hat{\mathrm{Y}}=$ $0.421 \mathrm{X}-0.044(\mathrm{r}=0.932, \mathrm{P}<0.001)$; the intercept did not differ significantly from zero. The least-squares line forced through the 0,0 point gave the regression line $\hat{Y}=0.411 \mathrm{X}$ $(\mathrm{n}=15 ; \mathrm{r}=0.932 ; \mathrm{P}<0.001)$. This correlation (graph not shown) and the random scatter of the six points from the Shand et al. data about the regression line (three of the six points were essentially on the regression line) indicated that adjustments to dosage and dosage interval data to make them compatible with those of Freedman et al. were justifiable.

Correlation of $\mathrm{Y}=\overline{\mathrm{C}}_{\mathrm{ss}}$ with $\mathrm{X}=\mathrm{AUC}^{0-x} / 6$ by the method of least squares forced through the 0,0 point gave the regression line $\hat{\mathrm{Y}}=$ $2.41 \mathrm{X}(\mathrm{n}=15 ; \mathrm{r}=0.923 ; \mathrm{P}<0.001)$. The plot is shown as Fig. 1. The mean absolute (sign ignored) deviation of a predicted $\overline{\mathrm{C}}_{\mathrm{ss}}$ from the observed $\overline{\mathrm{C}}_{\mathrm{ss}}$ concentration was $18.4 \mathrm{ng} / \mathrm{ml}$ or $11.1 \%$. It should be noted that the reciprocal of the slope of the $\mathrm{Cl}_{\mathrm{po}}^{\mathrm{ss}} \mathrm{vs} \mathrm{Cl}_{\mathrm{po}}^{\mathrm{s}}$ regression, namely $1 / 0.411=2.43$, is essentially identical with the slope 2.41 of the $\overline{\mathrm{C}}_{\mathrm{ss}}$ vs AUC $\mathrm{AU}^{0-x} / 6$ regression, as expected.

Children. Table I lists the verapamil plasma concentrations measured after infusion follow- ing the bolus dose of $0.1 \mathrm{mg} / \mathrm{kg}$ and constantrate infusion of $0.14 \mathrm{mg} / \mathrm{kg}$ (total intravenous dose, $0.24 \mathrm{mg} / \mathrm{kg}$ ) given over $20 \mathrm{~min}$. Table II gives the results of computer fitting of the data shown in Table I to equation 1 and also the $C_{i}$ values corresponding to equation 2 and a single $0.1-\mathrm{mg} / \mathrm{kg}$ bolus intravenous dose of verapamil. The sum of squared deviations and $r^{2} s$ for the fits are also listed in Table II. The last row in Table II lists the percentage contribution of the terminal log-linear phase, i.e., the $\mathrm{C}_{1} \mathrm{e}^{-\lambda 1 \mathrm{t}}$ term, to the $\mathrm{AUC}^{0-\infty}$ corresponding to a single $0.1-\mathrm{ng} / \mathrm{kg}$ bolus dose. Results of fitting two of the seven sets of postinfusion data are shown in Fig. 2.

By the use of the intravenous dose of 0.1 $\mathrm{mg} / \mathrm{kg}$ and the $C_{1}$ and $\lambda_{i}$ values of Table II, kinetic parameters for verapamil in children were estimated by established methods ${ }^{20,21}$ and are listed in Table III. In addition, the last row of Table III lists the percentage of error in the clearance of verapamil if only the monoexponential equation $C_{p}=C_{1} e^{-\lambda_{1},}$ is used rather than the polyexponential equation 2 (see footnote to Table III for the appropriate equations to make such estimates).

Table IV lists the oral doses given to the children, the $D_{p o} / D_{i v} s$ used in subsequent correlations, and the measured plasma $\mathrm{C}_{\mathrm{ss}}^{\min } \mathrm{s}$ of ver- 
Table II. Parameters from nonlinear least-squares fitting of postinfusion verapamil plasma concentrations after a bolus dose of $0.1 \mathrm{mg} / \mathrm{kg}$ and the infusion of $0.14 \mathrm{mg} / \mathrm{kg}$ given at a rate of $0.42 \mathrm{mg} / \mathrm{kg} / \mathrm{hr}(0.007 \mathrm{mg} / \mathrm{kg} / \mathrm{min})$ over $0.333 \mathrm{hr}(20 \mathrm{~min})$

\begin{tabular}{|c|c|c|c|}
\hline \multirow[b]{2}{*}{ Parameter } & \multicolumn{3}{|c|}{ Subject } \\
\hline & $M a^{*}$ & $B u \dagger$ & $V^{*}$ \\
\hline$\lambda_{1}\left(\mathrm{hr}^{-1}\right)$ & $\begin{array}{c}0.0391 \\
(0.0316)\end{array}$ & $\begin{array}{c}0.0737 \\
\ddagger\end{array}$ & $\begin{array}{c}0.0405 \\
(0.0518)\end{array}$ \\
\hline$\lambda_{2}\left(\mathrm{hr}^{-1}\right)$ & $\begin{array}{c}0.569 \\
(0.168)\end{array}$ & 3.36 & 4.07 \\
\hline$\lambda_{3}\left(\mathrm{hr}^{-1}\right)$ & $\begin{array}{l}6.37 \\
(0.332)\end{array}$ & 8.62 & \\
\hline $\mathrm{Z}_{1}(\mathrm{ng} / \mathrm{ml})$ & $\begin{array}{l}12.78 \\
(5.14)\end{array}$ & 74.97 & $\begin{array}{l}17.90 \\
(5.87)\end{array}$ \\
\hline $\mathrm{Z}_{2}(\mathrm{ng} / \mathrm{ml})$ & $\begin{array}{l}40.96 \\
(4.92)\end{array}$ & 100.6 & $\begin{array}{c}103.0 \\
(7.78)\end{array}$ \\
\hline $\mathrm{Z}_{3}(\mathrm{ng} / \mathrm{ml})$ & $\begin{array}{c}199.3 \\
(5.51)\end{array}$ & 139.4 & - \\
\hline $\mathrm{C}_{1}(\mathrm{ng} / \mathrm{ml})$ & 5.325 & 31.80 & 7.534 \\
\hline $\mathrm{C}_{2}(\mathrm{ng} / \mathrm{ml})$ & 19.49 & 86.11 & 100.6 \\
\hline $\mathrm{C}_{3}(\mathrm{ng} / \mathrm{ml})$ & 284.7 & 587.4 & - \\
\hline$\Sigma \operatorname{dev}^{2}$ & 6.96 & 39.2 & 85.3 \\
\hline$r^{2} \|$ & 0.9999 & 0.9991 & 0.9956 \\
\hline $\begin{array}{l}\mathrm{AUC}^{0-x}\left(\frac{\mathrm{ng}}{\mathrm{ml}} \times \mathrm{hr}\right) \\
\text { for } 0.1-\mathrm{mg} / \mathrm{kg} \mathrm{IV} \\
\text { bolus dose }\end{array}$ & 215 & 525 & 211 \\
\hline $\begin{array}{l}\text { \% Contribution of terminal } \\
\text { log-linear phase to the } \\
\text { AUC } \\
\text { bolus dose }\end{array}$ & 63.3 & 82.2 & 88.2 \\
\hline
\end{tabular}

Values in parenthesis are SDs of estimated parameters. The equation fitted to postinfusion plasma concentrations of verapamil was: $\mathrm{C}=\sum_{\mathrm{i}=1}^{\mathrm{n}} \mathrm{Z}_{\mathrm{i}} \mathrm{e}^{-\lambda_{\mathrm{i}} \mathrm{t}}$, where $\mathrm{n}=2$ or 3 and $\mathrm{t}=$ time after cessation of the infusion. The corresponding equation if only the $0.1-\mathrm{mg} / \mathrm{kg}$ bolus dose had been administered is: $C=\sum_{i=1}^{n} C_{i} e^{-\lambda_{1} t}$, where $t=$ time after injection and $C_{i}=\frac{Z_{i}}{\frac{4.2}{\lambda_{i}}-\left(\frac{4.2}{\lambda_{1}}-1\right) e^{-0.333 \lambda_{2}}} \cdot C V=$ coefficient of variation; $\Sigma \operatorname{dev}^{2}=$ sum of squared deviations.

* Data were fitted with the Apple II microcomputer using a program written by Dr, J. L. Fox using equal weights.

†Data were fitted with the program NONLIN written by Dr. C. M. Metzler using the central campus computer with weighting according to the reciprocals of the concentrations.

¥No SDs were obtained since there were too few data points for the number of estimated parameters.

$\S$ No SDs were obtained as a result of a problem with the computer program.

$\| \mathrm{r}^{2}=1-\frac{\Sigma \mathrm{dev}^{2}}{\mathrm{~s}_{\mathrm{y}}^{2}}$, where $\mathrm{s}_{\mathrm{y}}^{2}=\Sigma \mathrm{C}_{\mathrm{i}}^{2}-\left(\Sigma \mathrm{C}_{\mathrm{i}}\right)^{2} / \mathrm{N}$.

I\% Contribution $=100 \frac{C_{1}}{\lambda_{1}} / \mathrm{AUC}^{0-\infty}$, where $\mathrm{AUC}^{0-x}=\Sigma \mathrm{C}_{\mathrm{i}} / \lambda_{\mathrm{i}}$ corresponding to the $0.1-\mathrm{mg} / \mathrm{kg}$ IV bolus dose.

apamil and norverapamil after 1 mo of oral therapy.

With the starred terminal postinfusion plasma concentrations shown in Table I and the equation shown in the footnote to Table I, the parameters $C_{0}, \lambda_{z}$, and the $t^{1 / 2}\left(0.693 / \lambda_{z}\right)$ were estimated and are shown in Table $V$. In six of our seven children the $t^{1} \frac{1}{2}$ estimated as $0.693 / \lambda_{z}$ was shorter than that estimated as $0.693 / \lambda_{1}$ (Table III). The mean $\mathrm{t}^{1 / 2}\left(0.693 / \lambda_{\mathrm{z}}\right)$ of $6.40 \mathrm{hr}$ and mean $t^{1 / 2}\left(0.693 / \lambda_{1}\right)$ of $9.17 \mathrm{hr}$ differed by paired $t$ test $(P=0.05)$. This suggests that polyexponential fitting is necessary to estimate the appropriate elimination rate constant and $t^{1 / 2}$. 


\begin{tabular}{|c|c|c|c|c|c|}
\hline \multicolumn{4}{|c|}{ Subject } & \multirow[b]{2}{*}{ Mean } & \multirow[b]{2}{*}{$C V(\%)$} \\
\hline $\mathrm{Me}^{\dagger}$ & $T^{\dagger}$ & $H^{*}$ & $B o \dagger$ & & \\
\hline \multirow{3}{*}{$\begin{array}{c}0.197 \\
\S \\
1.80\end{array}$} & 0.160 & 0.0865 & 0.167 & 0.109 & 59.3 \\
\hline & $\begin{array}{c}(0.238) \\
2.605\end{array}$ & $\begin{array}{c}(0.0281) \\
0.949\end{array}$ & $\begin{array}{c}(0.0493) \\
4.70\end{array}$ & 2.58 & 60.5 \\
\hline & $(24.8)$ & $(0.563)$ & $(2.19)$ & & \\
\hline 114.3 & $\begin{array}{r}4.56 \\
(56.9)\end{array}$ & $\begin{array}{l}11.15 \\
(0.941)\end{array}$ & - & \multirow[t]{7}{*}{-} & \multirow[t]{7}{*}{-} \\
\hline \multirow[t]{2}{*}{57.35} & $(6.265$ & 36.08 & 28.70 & & \\
\hline & $(9.81)$ & $(11.5)$ & $(3.97)$ & & \\
\hline \multirow{2}{*}{95.88} & 51.05 & 40.99 & 27.18 & & \\
\hline & $\left(1.8 \times 10^{3}\right)$ & $(9.74)$ & $(4.73)$ & & \\
\hline \multirow[t]{2}{*}{114.7} & 44.31 & 180.7 & - & & \\
\hline & $\left(1.8 \times 10^{3}\right)$ & $(9.16)$ & & & \\
\hline 25.04 & 2.712 & 15.35 & 12.44 & & \\
\hline 59.88 & 37.67 & 21.26 & 29.68 & & \\
\hline 3121. & 49.03 & 461.1 & - & & \\
\hline 228.3 & 70.3 & 32.5 & 15.9 & & \\
\hline 0.9961 & 0.9991 & 0.9994 & 0.9908 & & \\
\hline 188 & 42.2 & 241 & 180 & 229 & 63.6 \\
\hline 67.7 & 40.2 & 73.6 & 41.4 & 65.2 & 28.6 \\
\hline
\end{tabular}

Table VI summarizes results of the best correlations of the oral $\mathrm{C}_{\mathrm{ss}}^{\min }$ values with functions derived from the single-dose intravenous data in children. The best correlation is that of row A of Table VI and the correlations become progressively poorer as one proceeds to row $\mathrm{F}$. Correlations were made with the functions shown in the third column of Table VI at various times $t$ and only the best correlation (optimum $t$ value) of each type is shown in the table. The functions are as follows: (A) plasma verapamil $\mathrm{C}_{\mathrm{p}}^{\mathrm{iv}}$ at $3 \mathrm{hr}$ after dosing when bolus intravenous doses are given every $6 \mathrm{hr}$, (B) plasma verapamil $\mathrm{C}_{\mathrm{p}}^{\mathrm{iv}}$ at 3 $\mathrm{hr}$ after dosing when both bolus doses and infusions are given intravenously, as in our protocol, (C) plasma verapamil $\mathrm{C}_{\mathrm{p}}^{\mathrm{iv}}$ at $12 \mathrm{hr}$ after a single intravenous bolus dose, (D) plasma verapamil $\mathrm{C}_{\mathbf{p}}^{\mathrm{iv}}$ at $12 \mathrm{hr}$ after a bolus dose and an infusion, as in our protocol, (E) as in function A except only terminal intravenous data are used
(Table $\mathrm{V}$ ) and $\mathrm{t}=4 \mathrm{hr}$ rather than $3 \mathrm{hr}$, and $(\mathrm{F})$ as in function $\mathrm{C}$ except only terminal intravenous data are used and $t=9 \mathrm{hr}$ rather than 12 $\mathrm{hr}$. In all the correlations the predicted intravenous concentrations correspond to the oral doses (as a result of the use of the $D_{p o} / D_{I V}$ ratios shown in Table IV). Confirmation of these correlations should not be attempted by experimental means since the oral doses are too high to be given intravenously, but a lower dose could be given and the dose ratio $D_{p o} / D_{I V}$ could be used to correct the measured values. It should be noted that as the $r^{2}$ and $r$ values decrease, the mean absolute deviations in a predicted $\mathrm{C}_{\mathrm{ss}}^{\min }$ increase considerably (Table VI).

Table VII lists the verapamil and norverapamil plasma concentrations in patient $\mathrm{Bo}$, who was given an oral dose of $40 \mathrm{mg}$ of verapamil $24 \mathrm{hr}$ after the intravenous doses. The equation fitting the verapamil data (footnote to 
Table III. Verapamil kinetics estimated from doses, body weights, and the data in Table II

\begin{tabular}{|c|c|c|c|c|c|c|c|c|c|}
\hline \multirow[b]{2}{*}{ Parameter } & \multicolumn{7}{|c|}{ Subject } & \multirow[b]{2}{*}{ Mean } & \multirow{2}{*}{$\begin{array}{l}C V \\
(\%)\end{array}$} \\
\hline & $M a$ & $B u$ & V & $M e$ & $T$ & $H$ & Bo & & \\
\hline $\begin{array}{l}\text { Total IV dose } \\
\text { (mg }\end{array}$ & 23.0 & 16.7 & 11.8 & 16.3 & 5.40 & 11.8 & 8.16 & 13.3 & 44.3 \\
\hline Age (yr) & 19 & 16 & 12 & 15 & 7 & 8 & 10 & 12 & 37 \\
\hline Body wt. (kg) & 95.8 & 69.5 & 49.1 & 67.9 & 22.5 & 49.1 & 34.0 & 55.4 & 44.3 \\
\hline $\begin{array}{l}\text { Clearance } \\
(l / \mathrm{min})\end{array}$ & 0.742 & 0.221 & 0.389 & 0.604 & 0.888 & 0.339 & 0.315 & 0.500 & 49.7 \\
\hline $\mathrm{V}_{\mathrm{p}}(l)$ & 31.0 & 9.88 & 45.4 & 2.12 & 25.2 & 9.88 & 80.8 & 29.2 & 93.0 \\
\hline $\mathrm{V}_{\mathrm{ss}}(l)$ & 735 & 148 & 509 & 128 & 144 & 175 & 111 & 279 & 87.6 \\
\hline $\mathrm{V}_{\beta}(l)$ & 1139 & 180 & 576 & 184 & 333 & 235 & 113 & 394 & 91.9 \\
\hline$V_{\mathrm{de} x t}(l)$ & 1800 & 219 & 653 & 271 & 830 & 319 & 115 & 601 & 97.6 \\
\hline $1 / 22^{*}(\mathrm{hr})$ & 17.7 & 9.40 & 17.1 & 3.51 & 4.33 & 8.01 & 4.15 & 9.17 & 65.7 \\
\hline $\mathrm{MRT}_{\dagger}^{\dagger}(\mathrm{hr})$ & 16.5 & 11.2 & 21.8 & 3.53 & 2.70 & 8.60 & 5.87 & 10.0 & 70.4 \\
\hline $\begin{array}{l}\text { \% error in } \\
\text { clearance if } \\
\text { monoex- } \\
\text { ponential } \\
\text { equation } \\
\text { used } \neq\end{array}$ & 58.0 & 21.7 & 13.3 & 47.7 & 149 & 35.9 & 8.5 & 47.7 & 101 \\
\hline
\end{tabular}

$V_{p}=$ plasma volume; $V_{s s}=$ volume of distribution at steady state; $V_{\beta}=$ volume of distribution area; $V_{d e x t}=$ volume of distribution extrapolated.

${ }^{*}$ Elimination $t^{1} / 2=0.693 / \lambda_{1}$.

tMRT $=$ mean residence time $=\Sigma\left(C_{i} / \lambda_{i}^{2}\right) / \Sigma\left(C_{i} / \lambda_{i}\right)$ (see Table II for $C_{1}$ and $\lambda_{i}$ values).

$\$ \%$ Error $=100\left[\frac{\lambda_{1}}{C_{1}}\left(\frac{C_{2}}{\lambda_{2}}+\frac{C_{3}}{\lambda_{3}}\right)\right]$ for triexponential equation: $C=C_{1} e^{-\lambda_{1} t}+C_{2} e^{-\lambda_{2} t}+C_{3} e^{-\lambda_{3}{ }^{1}}$ and $\%$ error $=100\left[\frac{\lambda_{1} C_{2}}{C_{1} \lambda_{2}}\right]$ for biexponential equation; $C=C_{1} \mathrm{e}^{-\lambda_{1} \mathrm{t}}+\mathrm{C}_{2} \mathrm{e}^{-\lambda_{2} \mathrm{t}}$

Table VII) has $0.337 \mathrm{hr}^{-1}$ as the smallest $\lambda_{\mathrm{i}}$ value, which corresponds to a t $1 / 2$ of $2 \mathrm{hr}$. Since this $t \frac{1}{2}$ is considerably smaller than any other measured (Tables III and VI), we concluded that the 4-hr sampling period was insufficient to define the log-linear phase.

\section{Discussion}

Adults. The hypothesis of Freedman et al. that "kinetic predictions based on single doses will not give reliable estimates for long-term oral dosage" ${ }^{5}$ appears untenable in light of Fig. 1. From usual linear kinetic theory one would expect the slope of the line in Fig. 1 to be equal to unity. However, the fact that the slope is 2.41 does not detract from the excellent predictability of plasma verapamil $\overline{\mathrm{C}}_{\mathrm{ss}} \mathrm{s}$ after longterm oral therapy from the concentrations measured after a single dose of the drug. The slope of 2.41 indicates that the plasma clearance of verapamil decreases 2.4-fold (from 3.6 to 1.5 $l / \mathrm{min}$ ) during the time from administration of the single or first dose to the steady state as clearly pointed out by Freedman et al. and
Shand et al. The remarkable thing indicated by the correlation is the relative uniformity of the fractional or percentage reduction in oral clearance (or increase in AUC per $80 \mathrm{mg}$ oral dose) from person to person. The correlation in Fig. 1 involves only oral dosing, hence the first-pass effect is involved in both the single-dose and steady-state results. However, some or all of the factors involved in the first pass, namely bioavailability (or extraction ratio), hepatic clearance, and possibly effective liver blood flow, must change considerably to account for the slope of 2.41. Since the individual subject verapamil plasma concentrations after the single or first doses and those obtained at steady state were not available in the articles of Freedman et al. and Shand et al., single-point correlations, as described by others, ${ }^{8,}, 9,17,18$ could not be studied, but such studies may be fruitful.

Children. Since there is extensive first-pass metabolism of verapamil the challenge to predict $\mathrm{C}_{\mathrm{ss}}^{\min }$ for long-term oral therapy from single-dose intravenous data was considerable. When the observed verapamil plasma concen- 
Table IV. Oral doses and plasma $C_{\mathrm{ss}}^{m i n} s$ of verapamil and norverapamil after approximately 1 mo of oral dosing

\begin{tabular}{|c|c|c|c|c|c|}
\hline \multirow[b]{2}{*}{ Subject } & \multicolumn{2}{|c|}{$D_{p o} q . i . d}$. & \multirow[b]{2}{*}{$D_{p o} / D_{i v}{ }^{*}$} & \multicolumn{2}{|c|}{$C_{s s}^{\min }$} \\
\hline & $m g$ & $\mathrm{mg} / \mathrm{kg}$ & & Verapamil & Norverapamil \\
\hline $\mathrm{Ma}$ & 80 & 0.835 & 3.48 & 99 & 129 \\
\hline $\mathrm{Bu}$ & 80 & 1.15 & 4.79 & 225 & 159 \\
\hline V & 80 & 1.63 & 6.79 & 136 & 114 \\
\hline $\mathrm{Me}$ & 80 & 1.18 & 4.92 & 63 & 70 \\
\hline $\mathrm{T}$ & 40 & 1.78 & 7.42 & 25 & 61 \\
\hline $\mathrm{H}$ & 40 & 0.815 & 3.40 & 66 & - \\
\hline & & & $\begin{array}{l}\mathrm{n} \text { for } 80 \mathrm{mg}= \\
\mathrm{n} \text { for } 40 \mathrm{mg}=\end{array}$ & $\begin{array}{r}131 \\
33\end{array}$ & \\
\hline
\end{tabular}

*The $D_{p}$ used is the $\mathrm{mg} / \mathrm{kg}$ oral dose shown in column 3 . The $\mathrm{D}_{\mathrm{fv}}$ used was $0.24 \mathrm{mg} / \mathrm{kg}(0.1$ bolus and 0.14 infusion $)$. These dose ratios were used when $Z_{i}$ was involved, but ratjos 2.4 times larger were used with $C_{i}$ values since they corresponded to $D_{i v}$ values of $0.1 \mathrm{mg} / \mathrm{kg}$.

trations at a given time after infusion (Table I) were correlated with the $\mathrm{C}_{\mathrm{ss}}^{\min } \mathrm{s}$ after 1 mo of oral therapy (Table IV), the best correlation was obtained for $\mathrm{t}=4 \mathrm{hr}$ and for that correlation $\left(r^{2}=0.751\right)$. The latter is lower than any $\mathrm{r}^{2}$ value in Table VI. Hence, for accurate prediction of oral $\mathrm{C}_{\mathrm{ss}} \mathrm{s}$ polyexponential fitting of the intravenous single-dose data was necessary. The concept of "mapping" the parameter space (varying time $t$ in the functions of Table VI) to uncover the optimum time after dosing to use in correlations of $\overline{\mathrm{C}}_{\mathrm{ss}} \mathrm{s}$ with these other parameters obtained from single-dose data appears to be novel. This approach with the children's verapamil data has disclosed that, at least in this case, projecting single-dose intravenous data to steady state (A and B, Table VII) considerably improves predictability-i.e., provides higher $\mathrm{r}^{2}$ values. Also, when estimated intravenous concentrations at different times after a single dose were used in the correlations the predictability appeared to improve as time after dosing increased, but $\mathrm{r}^{2}$ appeared to approach an asymptotic value as $t$ increased. Such information may be useful in correlations of the type described by other authors. ${ }^{8,9}, 17,18$

Our observations, listed in Table VII, concerning length of the blood sampling time are related to other observations we have made concerning data in the literature. The 6-hr sampling period of Dominic et al. ${ }^{1}$ was not long enough to reach the true log-linear phase since they reported an average $t^{1 / 2}$ of $1.8 \mathrm{hr}$, which is considerably shorter than that reported by others. ${ }^{2,3}, 5,6,11,15,22$ The mean elimination $t^{1 / 2}$ of $9.17 \mathrm{hr}$ that we obtained in children by
Table V. Parameters of the equation $C=C_{0} e^{-\lambda_{z} t}$ estimated from terminal postinfusion data only*

\begin{tabular}{c|c|c|c}
\hline Subject & $\begin{array}{c}C_{o} \\
(n g / m l)\end{array}$ & $\begin{array}{c}\lambda_{z} \\
\left(h r^{-1}\right)\end{array}$ & $\begin{array}{c}t^{1 / 2} \\
(h r)\end{array}$ \\
\hline $\mathrm{Ma}$ & 16.86 & 0.0579 & 12.0 \\
$\mathrm{Bu}$ & 108.2 & 0.165 & 4.2 \\
$\mathrm{~V}$ & 21.65 & 0.0651 & 10.6 \\
$\mathrm{Me}$ & 45.33 & 0.164 & 4.2 \\
$\mathrm{~T}$ & 6.082 & 0.153 & 4.5 \\
$\mathrm{H}$ & 43.91 & 0.105 & 6.6 \\
Bo & 33.57 & $\underline{0.257}$ & $\mathbf{2 . 7}$ \\
\cline { 2 - 3 } & Mean 39.4 & 0.138 & 6.4 \\
\hline
\end{tabular}

* See footnote to Table I for data used.

polyexponential fitting was longer than the mean $t^{1 / 2}$ of $6.40 \mathrm{hr}$ that we obtained by use of only terminal concentrations; even the latter is longer than the $t^{1 / 2}$ in adults reported by others. ${ }^{1-3}, 5,6,11,15,22$ The mean clearance of $0.500 \mathrm{l} / \mathrm{min}$ we found in the seven children is also lower than the mean clearances in the range 0.576 to $1.57 \mathrm{l} / \mathrm{min}$ reported for adults by others. $1,3,5,6,11,22$ Thus, it appears that both the clearance and elimination rate constant of verapamil may be smaller in children than in adults. This is so even when it is normalized to body weight; the mean clearance was 11.9 (7.32 omitting patient $\mathrm{T}$ ) $\mathrm{ml} / \mathrm{min} / \mathrm{kg}$ in the seven (or six) children. In general, evaluation of our child data and the adult data of Eichbaum et al. ${ }^{3}$ and Kates et al. ${ }^{6}$ indicated that normalizing clearances and volumes of distribution of verapamil for body weight does not lower coefficients of variation, but, in fact, usually raises 
Table VI. Prediction of plasma verapamil $C_{\mathrm{ss}}^{m i n}$ for oral therapy from verapamil plasma concentrations measured after single intravenous doses

\begin{tabular}{|c|c|c|c|c|c|c|c|c|}
\hline \multirow[b]{2}{*}{ Code } & \multirow[b]{2}{*}{ Abscissa, $X^{*}$} & \multirow{2}{*}{$\begin{array}{c}\text { Method of } \\
\text { calculation of } X \\
\end{array}$} & \multicolumn{2}{|c|}{$\hat{Y}=a+b X$} & \multicolumn{2}{|c|}{ Coefficients $\dagger$} & \multicolumn{2}{|c|}{$\begin{array}{c}\text { Mean } \\
\text { deviation } \ddagger\end{array}$} \\
\hline & & & Intercept, $a$ & Slope, $b$ & $r^{2}$ & $r$ & $n g / m l$ & $\%$ \\
\hline A & $\begin{array}{l}\hat{\mathrm{C}}_{\mathrm{ss}}(\mathrm{B}) \\
\quad \mathrm{t}=3, \tau=6\end{array}$ & $\frac{D_{p o}}{D_{i v}} \sum_{i=1}^{n} \frac{C_{i} e^{-\lambda_{1} t}}{1-e^{-\lambda_{i} \tau}}$ & 12.0 & 0.257 & 0.971 & $0.985 \S$ & 8.43 & 10.1 \\
\hline B & $\begin{array}{l}\hat{C}_{\text {Cs }}(B+I), \\
\quad t=3, \tau=6\end{array}$ & $\frac{D_{p o}}{D_{i v}} \sum_{i=1}^{n} \frac{Z_{i} e^{-\lambda_{i} t}}{1-e^{-\lambda_{i} \tau}}$ & 14.6 & 0.246 & 0.963 & $0.981 \S$ & 9.67 & 11.7 \\
\hline $\mathrm{C}$ & $\hat{\mathrm{C}}(\mathrm{B}), \mathrm{t}=12$ & $\frac{D_{p 0}}{D_{i v}} \sum_{i=1}^{n} C_{i} e^{-\lambda_{i} t}$ & 29.4 & 0.556 & 0.931 & $0.965 \|$ & 13.0 & 21.5 \\
\hline D & $\begin{array}{c}\hat{\mathrm{C}}(\mathrm{B}+\mathrm{I}) \\
\quad \mathrm{t}=12\end{array}$ & $\frac{D_{p o}}{D_{i v}} \sum_{i=1}^{n} Z_{i} e^{-\lambda_{1} t}$ & 29.5 & 1.33 & 0.930 & $0.964 \|$ & 13.1 & 21.5 \\
\hline $\mathrm{E} \mathbb{q}$ & $\begin{array}{l}\hat{C}_{s s}(B+I), \\
\quad t=4, \tau=6\end{array}$ & $\frac{\mathrm{D}_{\mathrm{po}}}{\mathrm{D}_{\mathrm{iv}}}\left[\frac{\mathrm{C}_{\mathrm{v}} \mathrm{e}^{-\lambda_{2} \mathrm{t}}}{1-\mathrm{e}^{-5.667 \lambda_{z}}}\right]$ & -5.5 & 0.453 & 0.855 & $0.924 \|$ & 23.7 & 29.6 \\
\hline $\mathbf{F} \mid$ & $\begin{array}{c}\hat{C}(B+I) \\
t=9\end{array}$ & $\frac{D_{p o v}}{D_{i v}}\left[C_{0} e^{-\lambda_{z}{ }^{t}}\right]$ & -1.7 & 1.76 & 0.845 & $0.919 \|$ & 22.1 & 28.8 \\
\hline
\end{tabular}

*The predicted verapamil concentrations for intravenous therapy correspond to those expected for doses equivalent to the oral doses (Table IV). $\hat{C}_{\mathrm{ss}}(\mathrm{B})$ refers to predicted steady-state concentration for bolus doses of $0.1 \mathrm{mg} / \mathrm{kg}$ given every $\tau$ hr where $t$ is the time after dosing at steady state. $\hat{C}_{s s}(B+I)$ refers to the predicted concentration for a bolus + infusion regimen as used in this study but repeated every $\tau$ hr to steady state. $\hat{\mathbf{C}}(\mathbf{B})$ and $\hat{\mathrm{C}}(\mathbf{B}+\mathrm{I})$ refer to predicted concentrations after single bolus doses and bolus + infusion doses.

$t_{I}$ is the correlation coefficient for the linear regression of $Y$ (the observed verapamil C ${ }_{s}{ }^{m i n}$ shown in Table IV) and the $X$ shown in columns 2 and 3 above.

$¥$ The mean absolute (sign ignored) deviation of the predicted from the observed verapamil plasma concentration

$\$ \mathrm{P}<0.001$.

$\| \mathrm{P}<0.01$.

IIn these correlations only terminal postinfusion data were used (see Tables I and V).

Table VII. Plasma concentrations of verapamil and norverapamil in subject $B o$ after $40 \mathrm{mg}$ of oral verapamil $24 \mathrm{hr}$ after a bolus dose of $0.1 \mathrm{mg} / \mathrm{kg}$ and an infusion of $0.14 \mathrm{mg} / \mathrm{kg}$ over $20 \min$

\begin{tabular}{l|c|c}
\hline \multirow{2}{*}{$\begin{array}{c}\text { Time after } \\
\text { oral dose }(\mathrm{hr})\end{array}$} & \multicolumn{2}{|c}{ Plasma concentration $(\mathrm{ng} / \mathrm{ml})$} \\
\cline { 2 - 3 } & Verapamil $^{*}$ & Norverapamil \\
\hline 0 & 0 & 0 \\
0.25 & 74 & 31 \\
0.5 & 61 & 31 \\
0.75 & 58 & 44 \\
1 & 48 & 31 \\
2 & 40 & 37 \\
3 & 24 & 17 \\
4 & 18 & 18 \\
\hline
\end{tabular}

* Data from 0.25 to $4 \mathrm{hr}$ were fitted by the equation: $\mathrm{C}=$ $70.36 \mathrm{e}^{-0.337 t}+15.62 \mathrm{e}^{-2.83 t}$ where $\mathrm{t}=$ time of oral dosing. The higher value of 0.337 than those shown for $\lambda_{1}$ in Table II suggests that blood was not sampled long enough to observe the terminal loglinear phase. them. This accounts for the unit of measure in Table III being liters per minute or liters rather than liters per minute per kilogram or liters per kilogram. We also found no significant correlations of $\ln \mathrm{Y}$ with $\ln \mathrm{X}$ where $\mathrm{Y}=$ clearance, volume of distribution at steady state, volume of distribution area, volume of distribution extrapolated, $\mathrm{t}^{1 / 2}$, or mean residence time and $\mathrm{X}=$ body weight.

The last rows of Tables II and III indicate that verapamil should not be treated as a single exponential or one-compartment open model drug in therapeutic drug monitoring. At least in the seven children we studied, the error in such an approximation varies greatly from patient to patient.

\section{References}

1. Dominic JA, Bourne DWA, Tan TG, Kirsten EB, McAllister RG Jr: The pharmacology of 
verapamil III. J Cardiovasc Pharmacol 3:25-38, 1981.

2. Eichelbaum M, Dengler HJ, Somogyi A, von Unruh GE: Superiority of stable isotope techniques in the assessment of the bioavailability of drugs undergoing extensive first-pass elimination. Studies of the relative bioavailability of verapamil tablets. Eur J Clin Pharmacol 19: 127-131, 1981.

3. Eichelbaum M, Somogyi A, von Unruh GE, Dengler HJ: Simultaneous determination of the intravenous and oral pharmacokinetic parameters of D,L-verapamil using stable isotopelabelled verapamil. Eur J Clin Pharmacol 19: 133-137, 1981.

4. Flaim SF, Zelis R: Clinical use of calcium entry blockers. Fed Proc 40:2877-2881, 1981.

5. Freedman SB, Richmond DR, Ashley JJ, Kelly DT: Verapamil kinetics in normal subjects and patients with coronary artery spasm. CLIN Pharmacol Ther 30:644-652, 1981.

6. Kates RE, Keefe DLD, Schwartz J, Harapat S, Kirsten EB, Harrison DC: Verapamil disposition kinetics in chronic atrial fibrillation. CLIN PHARMACOL THER 30:44-51, 1981.

7. Keefe DL, Yee Y-G, Kates RE: Verapamil protein binding in patients and in normal subjects. Clin Pharmacol Ther 29:21-26, 1981.

8. Koup JR, Sack CM, Smith AL, Gibaldi M: Hypothesis for the individualization of drug dosage. Clin Pharmacokinet 4:460-469, 1979.

9. Koup JR, Sack CM, Smith AL, Neely NN, Gibaldi M: Rapid estimation of chloramphenicol clearance in infants and children. Clin Pharmacokinet 6:83-88, 1981 .

10. McAllister RG, Bourne DWA, Dittert LW: The pharmacology of verapamil. I. Elimination kinetics in dogs and correlation of plasma levels with effect on the electrocardiogram. J Pharmacol Exp Ther 202:38-44, 1977.

11. McAllister RG, Kirsten EB, Kerns GG, Kaplan CB: Verapamil kinetics and plasma level-effect relationships after IV and oral doses in normal subjects. Clin Res 29:705A, 1981.

12. McAllister RG, Todd GD, Slack JD, Shearer ME, Hobbs PJ: Hemodynamic and pharmacokinetic aspects of the interaction between propranolol and verapamil. Clin Res 29:755A, 1981.

13. Metzler CM: NONLIN, a computer program for parameter estimation in nonlinear situations. The Upjohn Company Technical Report 7292/ 69/7292/005, November 25, 1969.

14. Pedersen KE, Dorph-Pedersen A, Hvidt S, Klitgaard NA, Nielsen-Kudsk F: Digoxin-verapamil interaction. Clin Pharmacol Ther 30:311$316,1981$.

15. Shand DG, Hammill SC, Aanonsen L, Pritchett ELC: Reduced verapamil clearance during longterm oral administration. Clin Pharmacol THER 30:701-703, 1981.

16. Singhvi SM: Estimation of pharmacokinetic parameters from post-infusion blood level data obtained after simultaneous administration of intravenous priming and infusion doses. J Pharm Sci 66: 1499-1501, 1977.

17. Slattery JT, Gibaldi M, Koup JR: Prediction of maintenance dose required to attain a desired drug concentration at steady-state from a single determination of concentration after an initial dose. Clin Pharmacokinet 5:377-385, 1980.

18. Slattery JT: Single-point maintenance dose prediction: Role of interindividual differences in clearance and volume of distribution in choice of sampling time. J Pharm Sci 70:1174-1176, 1981.

19. Vasiliades J, Wilkerson K, Ellul D, Anticoli M: Rapid and sensitive procedure for the determination of verapamil and norverapamil by gaschromatography with a nitrogen-selective detector. Clin Chem 28:638-641, 1982.

20. Wagner JG: Fundamentals of clinical pharmacokinetics. Hamilton, Ill., 1975. Drug Intelligence Publications, Inc.

21. Wagner JG: Linear pharmacokinetic equations allowing direct calculation of many needed pharmacokinetic parameters from the coefficients and exponents, of polyexponential equations which have been fitted to the data. J Pharmacokinet Biopharm 4:443-467, 1976.

22. Woodcock BG, Reitbrock I, Vöhringer HF, Rietbrock N: Verapamil disposition in liver disease and intensive-care patients: Kinetics, clearance, and apparent blood flow relationships. Clin Pharmacol Ther 29:27-34, 1981.

23. Woodcock BG, Schulz W, Kober G, Rietbrock $\mathrm{N}$ : Direct determination of hepatic extraction of verapamil in cardiac patients. Clin PharmaCOL THER 30:52-56, 1981. 